Original Research

\title{
Exploring Carbon Emissions in China's Electric Power Industry for Low-Carbon Development: Drivers, Decoupling Analysis and Policy Implications
}

\author{
Yanmei Li, Qi Wang* \\ Department of Economics and Management, North China Electric Power University, Baoding, China
}

Received: 18 June 2018

Accepted: 2 August 2018

\begin{abstract}
As an important single source to carbon emissions, China's power industry should bear social responsibility for mitigating climate change. To explore what low-carbon development means for the industry, a novel approach that combines the extended multilevel LMDI model with Tapio algorithm was conducted to study the drivers of carbon emissions in the power industry and whether $\mathrm{CO}_{2}$ emissions from power output is out of sync with economic development, covering the period from 1996 to 2016. Our results come to the following:

1. Carbon emissions from electricity output are characterized by increases and volatility, with an average annual growth rate of $7.05 \%$. The carbon emission factor of electricity, facilitating to compute $\mathrm{CO}_{2}$ data, shows a decline.

2. The positive driving factors are economic activity effect $(169.53 \%)$, population scale effect $(9.29 \%)$, fuel mix structure effect $(0.41 \%)$, and electricity trade effect $(1.05 \%)$; the negative driving factors are electricity intensity effect $(-46.38 \%)$, power generation efficiency effect $(-24.93 \%)$, and power generation structure effect $(-8.97 \%)$.

3. Weak decoupling and expansive decoupling are the main status during the research period. The electricity intensity effect is the main force to promote the decoupling process.

4. The market-oriented reform in the power industry in 2003 has a significant effect. The generationside competition mechanism successfully changes the historical developmental trend of the decoupling elastic index.
\end{abstract}

Keywords: electric power sector; decoupling elasticity; drivers; competition mechanism 


\section{Introduction}

For economic development, all countries in the world cannot be separated from the consumption of fossil fuels. However, due to the pollutants produced after the use of fossil fuels, ecological problems have been instigated [1-2]. As stated by the Intergovernmental Panel on Climate Change (IPCC), the anthropogenic emissions of greenhouse gases consist of carbon dioxide $\left(\mathrm{CO}_{2}\right)$, methane $\left(\mathrm{CH}_{4}\right)$, nitrous oxide $\left(\mathrm{N}_{2} \mathrm{O}\right)$, hydrofluorocarbons (HFCs), perfluorocarbons ( $\mathrm{PFCs}$ ), sulfur hexafluoride $\left(\mathrm{SF}_{6}\right)$, hydro chlorofluorocarbons (HCFCs), and chlorofluorocarbons (CFCs). Fossil energy-related carbon dioxide is considered the main contributor to the exacerbation of climate, and it also becomes an intractable issue faced by the scientific and political sectors [3].

Since 2007, China has become the world's largest emitter of carbon dioxide, surpassing the United States. According to the latest data released by BP, in 2016, China had discharged 9123 million tons, accounting for $27.3 \%$ of the world's carbon emissions [4]. In fact, the burning of fossil fuels not only results in a surge in $\mathrm{CO}_{2}$, but also is responsible for approximately $70 \%$ of the domestic air pollution total [5-6].

China ranks first in electricity production in the world, and it is also the largest electric consumer. Without a doubt, carbon emissions from China's power industry is a major origin in China and throughout the world. Statistics show that in the past decade, the emission growth from China's power industry accounted for $49.1 \%$ of the country's total and $32.1 \%$ of the world's total [7]. After years of rapid increase, energy-related $\mathrm{CO}_{2}$ in China's power sector has reached more than $3671.1 \mathrm{Mt}$. If viewed as a separate country, China's electric power industry is presently the third largest $\mathrm{CO}_{2}$ emitter in the world [8]. Compared with developed countries, China is still in an accelerated stage of urbanization and industrialization. Inevitably, China needs more energy to support this process. The economic significance of low-carbon development lies in a low-carbon economy that pursues low energy consumption, low pollution, and low emissions. It was first proposed by the British government in 2003, the energy white paper, "The future of our energy: creating a low-carbon economy." As a single major contributor, the Chinese power industry is obliged to assist the current low-carbon development in China and even the world. The $13^{\text {th }}$ Five-Year Plan for Power Development formulated by the Chinese government and the electricity market reform launched in 2016 have provided a great opportunity for the transformation of the power industry. Given the robust development of society, all of society would rely more on electricity consumption. Thus, for this paper's purposes, it is feasible and practical to explore the driving factors of the power industry and its low-carbon development way.

In previous research on the power industry, the energy-related carbon indicators were central spots and can be roughly divided into three categories: carbon emissions, carbon intensity, and carbon productivity. For example, Wang et al. used data from Shandong Province to decompose the carbon emissions of the power industry using the multilevel LMDI method. The results showed that the energy mix effect and emission factors effect inhibited the growth of carbon emissions, and the power generation effect was the main reason for the increasing $\mathrm{CO}_{2}$ emissions [9]. Liu et al. decomposed the electricity carbon intensity, and found that the increase in thermal efficiency was the main force for decline [10]. Sun et al. applied the multi-dimensional decomposition to analyze the carbon productivity of China's power sector, and explored the technical improvements and structural adjustment contributions in terms of final power [11]. Other literatures closely related to this article are summarized in Table 1.

By observing the examined area, both domestic and foreign researchers had attached importance to carbon reduction in the power industry. We can also obtain information about the method applied to carbon decomposition: The LMDI, Laspeyres decomposition, and STIRPAT methods are the mainstream methods. However, the application of the STIRPAT method has limitations that continuous time series data are required to calculate the effect of various factors on carbon emissions at a certain period, and the factor selection has a strong subjectivity. The Logarithmic Mean Divisia Index (LMDI) and Laspeyres decomposition model are the more popular branches under the index decomposition analysis method (IDA). In contrast, Laspeyres technology cannot incorporate with negative values that lead to imaginary decomposition results (caused by logarithmic operation). Another commonly used decomposition analysis method (DA) is the structural decomposition analysis method (SDA), but it has a strict dependence on input-output data, which constrains the extensive application of SDA extremely in empirical research. Consequently, LMDI technology is favored in the current study of carbon emissions due to its advantages such as complete decomposition, path independence, and no residual term [23-24].

In fact, as early as in 1978, after a groundbreaking study conducted by Kraft et al. [25], the relationship between energy use and economic development has been widely considered by researchers [26-28]. These research results did not arrive at an unambiguous conclusion as to different periods, research areas, and methods. However, in the field of electric power industry, coupling extent between electric $\mathrm{CO}_{2}$ emissions and economic development is an emerging topic and severely deficient. Decoupling analysis becomes a key method for studying this issue.

Decoupling refers to undoing the traditional relationship between the two indicators. Initially, in 2000, the Organization for Economic Cooperation and Development (OECD) used it to investigate agricultural policies and assess environmental quality [29]. Later, the 
Table 1 . Summary of the literature on carbon indicators of the power industry.

\begin{tabular}{|c|c|c|c|}
\hline The author & Period & Methodology & Content or subject \\
\hline Xue-Ting Jiang et al [12]. & $1990-2014$ & Multilevel LMDI & $\begin{array}{l}\text { Decomposition of carbon emissions from electric output } \\
\text { in the US }\end{array}$ \\
\hline Wei Sun et al [13]. & $1997-2012$ & Laspeyres decomposition & $\begin{array}{l}\text { Regional characteristics of } \mathrm{CO}_{2} \text { emissions from China's } \\
\text { power generation }\end{array}$ \\
\hline Jianguo Zhou et al [14]. & $1995-2014$ & LMDI model & $\begin{array}{c}\text { Decomposing of carbon emissions in china's power } \\
\text { industry }\end{array}$ \\
\hline Caiqing Zhang et al [15]. & 1995-2014 & Hierarchical LMDI method & $\begin{array}{l}\mathrm{CO}_{2} \text { emissions from the power industry } \\
\text { in the Beijing-Tianjin-Hebei Region }\end{array}$ \\
\hline Dan Yan et al [16]. & $1990-2013$ & STIRPAT model & $\begin{array}{l}\text { Driving factor of carbon emissions in China's power } \\
\text { sector considering the macro environment }\end{array}$ \\
\hline M.Karmellos et al [17]. & 2000-2012 & LMDI method & $\begin{array}{c}\text { Driving factors of } \mathrm{CO}_{2} \text { emissions from the power sector } \\
\text { in the European Union countries }\end{array}$ \\
\hline A.R. Noorpoor et al [18]. & 2003-2013 & STIRPAT model & $\begin{array}{l}\text { Using regression to explore } \mathrm{CO}_{2} \text { emissions } \\
\text { from Iran's power sector }\end{array}$ \\
\hline Paul A. Steenhof et al [19]. & $1990-2008$ & Laspeyres decomposition & $\begin{array}{c}\text { Factors impacting Canada's electricity sector's GHG } \\
\text { emissions }\end{array}$ \\
\hline B.W. Ang et al [20]. & $1990-2013$ & LMDI model & $\begin{array}{l}\text { A global analysis of carbon emission intensity } \\
\text { in electricity production }\end{array}$ \\
\hline B.W. Ang et al [21]. & $1990-2013$ & LMDI model & Drives of electricity carbon intensity in ASEAN \\
\hline Guijing Chen et al [22]. & 2003-2015 & LMDI method & $\begin{array}{l}\text { Electric carbon productivity from the perspective of } \\
\text { production and consumption in region of China }\end{array}$ \\
\hline
\end{tabular}

decoupling analysis was extended to the environmental field, stemming from the drive-pressure-state-influenceresponse (DPSIR) framework, which reflect the link between the driving force and the environmental pressure corresponding time period. Recently, Wu et al. classified the decoupling analysis method into six types and analyzed its advantages and disadvantages [30]. Among them, the OECD decoupling method [31-32] and the Tapio model [33-35] are the common indicators to quantify the correlation extent between the two variable changes. But they differ in algorithm. Specifically, the Tapio index is more suitable for decomposition analysis than the OECD algorithm [36] then utilized in this study.

From the above literature, it can be concluded that the link between carbon emissions from the power output and economic development has not received enough attention, and the sample data for LMDI lagged behind. For this reason, the LMDI method and the latest data are performed to re-determine the forces of carbon emissions from China's electricity production, while considering the impact of electricity import and export in China for the first time. And then, the preferred Tapio algorithm is applied to estimate the decoupling of economic development and carbon emissions from power output. Based on this, factors that affect the decoupling state are quantitatively assessed in view of the LMDI outcomes. Finally, we do the further work - the effectiveness of the electricity market reform policy since 2003 is evaluated, by the fitted trend in the decoupling index.

\section{Material and Methods}

\section{LMDI Decomposition Method}

To conduct meticulous research on $\mathrm{CO}_{2}$ from the power sector, this paper will attempt to establish a carbon emission decomposition model for China's power industry during the period from 1996 to 2016, which improves the decomposition equations appropriately proposed by Zhang et al. [37] with introducing the power trading effect and population effect. Carbon emissions from China's electricity production (C) can be expressed as:

$$
\begin{gathered}
\mathrm{C}=\sum_{\mathrm{i}} \mathrm{C}_{\mathrm{i}}=\sum_{\mathrm{i}} \frac{\mathrm{C}_{\mathrm{i}}}{\mathrm{E}_{\mathrm{i}}} \times \frac{\mathrm{E}_{\mathrm{i}}}{\mathrm{E}} \times \frac{\mathrm{E}}{\mathrm{ELF}} \times \frac{\mathrm{ELF}}{\mathrm{EL}} \times \frac{\mathrm{EL}}{\mathrm{EC}} \times \frac{\mathrm{EC}}{\mathrm{GDP}} \times \frac{\mathrm{GDP}}{\mathrm{POP}} \times \mathrm{POP} \\
=\sum_{\mathrm{i}} \mathrm{CF}_{\mathrm{i}} \times \mathrm{ES}_{\mathrm{i}} \times \mathrm{GE} \times \mathrm{EFS} \times \mathrm{ET} \times \mathrm{ELI} \times \mathrm{EAG} \times \mathrm{POP}
\end{gathered}
$$

...where $\mathrm{C}_{\mathrm{i}}$ denotes carbon emissions based on fuel type $\mathrm{i}$; $\mathrm{E}_{\mathrm{i}}$ denotes energy consumption based on fuel type $\mathrm{i}$; $\mathrm{E}$ denotes total energy consumption used for power output; ELF denotes thermal power generation; EL denotes total power generation, consisting of thermal power, hydropower, nuclear power, wind power and so on; GDP denotes the gross domestic product; EC denotes total electricity consumption; and POP denotes the total population. $\mathrm{CF}_{\mathrm{i}}=\mathrm{C}_{\mathrm{i}} / \mathrm{E}_{\mathrm{i}}$ is the carbon emission coefficient of fuel $\mathrm{i} ; \mathrm{ES}_{\mathrm{i}}=\mathrm{E}_{\mathrm{i}} / \mathrm{E}$ is the proportion of fuel type $\mathrm{i}$ to total energy consumption; $\mathrm{GE}=\mathrm{E} / \mathrm{ELF}$ is the ratio of energy used and thermal power; EFS $=\mathrm{ELF} / \mathrm{EL}$ is the share 
of thermal power generation in total power generation; $\mathrm{ET}=\mathrm{EL} / \mathrm{EC}$ indicates the ratio of electricity production to electricity consumption; ELI = EC/GDP is electricity consumed per unit of GDP; and $\mathrm{EAG}=\mathrm{GDP} / \mathrm{P}$ is per capita output value.

According to the LMDI method given by Ang that take time factors into account, differentiating Formula (1) with respect to time yields:

$$
\stackrel{\mathrm{g}}{\mathrm{C}}=\sum_{\mathrm{i}} \stackrel{\mathrm{g}}{\mathrm{CF}_{\mathrm{i}}} \times \mathrm{ES}_{\mathrm{i}} \times \mathrm{GE} \times \mathrm{EFS} \times \mathrm{ET} \times \mathrm{ELI} \times \mathrm{EAG} \times \mathrm{POP}
$$$$
+\sum_{\mathrm{i}} \mathrm{CF}_{\mathrm{i}} \times \mathrm{ES}_{\mathrm{i}}^{\mathrm{g}} \times \mathrm{GE} \times \mathrm{EFS} \times \mathrm{ET} \times \mathrm{ELI} \times \mathrm{EAG} \times \mathrm{POP}
$$$$
+\sum_{\mathrm{i}} \mathrm{CF}_{\mathrm{i}} \times \mathrm{ES}_{\mathrm{i}} \times \stackrel{\mathrm{g}}{\mathrm{GE}} \times \mathrm{EFS} \times \mathrm{ET} \times \mathrm{ELI} \times \mathrm{EAG} \times \mathrm{POP}
$$$$
+\sum_{\mathrm{i}} \mathrm{CF}_{\mathrm{i}} \times \mathrm{ES}_{\mathrm{i}} \times \mathrm{GE} \times \stackrel{\mathrm{g}}{\mathrm{EFS}} \times \mathrm{ET} \times \mathrm{ELI} \times \mathrm{EAG} \times \mathrm{POP}
$$$$
+\sum_{\mathrm{i}} \mathrm{CF}_{\mathrm{i}} \times \mathrm{ES}_{\mathrm{i}} \times \mathrm{GE} \times \mathrm{EFS} \times \stackrel{\mathrm{g}}{\mathrm{ET}} \times \mathrm{ELI} \times \mathrm{EAG} \times \mathrm{POP}
$$$$
+\sum_{\mathrm{i}} \mathrm{CF}_{\mathrm{i}} \times \mathrm{ES}_{\mathrm{i}} \times \mathrm{GE} \times \mathrm{EFS} \times \mathrm{ET} \times \mathrm{ELI} \times \mathrm{EAG} \times \mathrm{POP}
$$

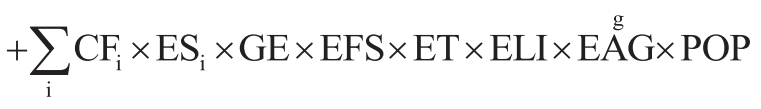$$
+\sum_{\mathrm{i}} \mathrm{CF}_{\mathrm{i}} \times \mathrm{ES}_{\mathrm{i}} \times \mathrm{GE} \times \mathrm{EFS} \times \mathrm{ET} \times \mathrm{ELI} \times \mathrm{EAG} \times \mathrm{PO} \mathrm{O} P
$$

The right side of Formula (2) can be written in the form of growth rate:

$$
\begin{array}{r}
\stackrel{g}{\mathrm{C}}=\sum_{\mathrm{i}} \mathrm{g}_{\text {cf }} \times \mathrm{C}_{\mathrm{i}}+\sum_{\mathrm{i}} \mathrm{g}_{\text {es }} \times \mathrm{C}_{\mathrm{i}}+\sum_{\mathrm{i}} \mathrm{g}_{\mathrm{ge}} \times \mathrm{C}_{\mathrm{i}}+\sum_{\mathrm{i}} \mathrm{g}_{\mathrm{efs}} \times \mathrm{C}_{\mathrm{i}} \\
+\sum_{\mathrm{i}} \mathrm{g}_{\mathrm{et}} \times \mathrm{C}_{\mathrm{i}}+\sum_{\mathrm{i}} \mathrm{g}_{\mathrm{eli}} \times \mathrm{C}_{\mathrm{i}}+\sum_{\mathrm{i}} \mathrm{g}_{\mathrm{eag}} \times \mathrm{C}_{\mathrm{i}}+\sum_{\mathrm{i}} \mathrm{g}_{\mathrm{pop}} \times \mathrm{C}_{\mathrm{i}}
\end{array}
$$

...where $g_{c f}, g_{\text {es }}, g_{\text {ge }}, g_{\text {efs }}, g_{\text {et }}, g_{\text {eli }}, g_{\text {ea }}$, and $g_{\text {pop }}$ are the growth rates of the carbon emission coefficient, fuel mix structure, power generation efficiency, thermal power share, power trade, power intensity, per capita output and population respectively. The next step is to integrate both sides of Formula (3) with respect to time interval $[\mathrm{t}, \mathrm{T}]$ :

$$
\begin{aligned}
\Delta \mathrm{C} & =\int_{\mathrm{t}}^{\mathrm{T}} \sum_{\mathrm{i}} \mathrm{g}_{\mathrm{cf}} \times \mathrm{C}_{\mathrm{i}} \mathrm{dt}+\int_{\mathrm{t}}^{\mathrm{T}} \sum_{\mathrm{i}} \mathrm{g}_{\mathrm{es}} \times \mathrm{C}_{\mathrm{i}} \mathrm{dt}+\int_{\mathrm{t}}^{\mathrm{T}} \sum_{\mathrm{i}} \mathrm{g}_{\mathrm{ge}} \times \mathrm{C}_{\mathrm{i}} \mathrm{dt}+\int_{\mathrm{t}}^{\mathrm{T}} \sum_{\mathrm{i}} \mathrm{g}_{\mathrm{efs}} \times \mathrm{C}_{\mathrm{i}} \mathrm{dt} \\
& +\int_{\mathrm{t}}^{\mathrm{T}} \sum_{\mathrm{i}} \mathrm{g}_{\mathrm{et}} \times \mathrm{C}_{\mathrm{i}} \mathrm{dt}+\int_{t}^{\mathrm{T}} \sum_{\mathrm{i}} \mathrm{g}_{\mathrm{eli}} \times \mathrm{C}_{\mathrm{i}} \mathrm{dt}+\int_{\mathrm{t}}^{\mathrm{T}} \sum_{\mathrm{i}} \mathrm{g}_{\mathrm{eag}} \times \mathrm{C}_{\mathrm{i}} \mathrm{dt}+\int_{\mathrm{t}}^{\mathrm{T}} \sum_{\mathrm{i}} \mathrm{g}_{\mathrm{pop}} \times \mathrm{C}_{\mathrm{i}} \mathrm{dt}
\end{aligned}
$$

Since the carbon emission coefficient set in this paper is a constant, the impact of the carbon emission factor is set to zero. From baseline year t to target year T, energyrelated carbon emissions in China's power industry can be accurately represented by seven components: (i) change in fuel mix effect $\left(\Delta \mathrm{C}_{\mathrm{es}}\right)$; (ii) change in power generation efficiency effect $\left(\Delta \mathrm{C}_{\mathrm{ge}}\right)$; (iii) change in electricity production structure effect $\left(\Delta \mathrm{C}_{\mathrm{efs}}\right)$; (iv) change in power trade effect $\left(\Delta \mathrm{C}_{\mathrm{et}}\right)$; (v) change in electricity intensity effect $\left(\Delta \mathrm{C}_{\mathrm{eli}}\right)$; (vi) change in economic activity effect $\left(\Delta \mathrm{C}_{\text {eag }}\right)$; and (vii) change in population size effect $\left(\Delta \mathrm{C}_{\mathrm{pop}}\right)$. Additive form is shown in Formula (5):

$\Delta \mathrm{C}=\Delta \mathrm{C}_{\mathrm{es}}+\Delta \mathrm{C}_{\mathrm{ge}}+\Delta \mathrm{C}_{\mathrm{efs}}+\Delta \mathrm{C}_{\mathrm{et}}+\Delta \mathrm{C}_{\mathrm{eli}}+\Delta \mathrm{C}_{\mathrm{eag}}+\Delta \mathrm{C}_{\mathrm{pop}}$

Each effect on the right side of the Formula (5) can be represented as:

$$
\begin{gathered}
\Delta \mathrm{C}_{\text {es }}=\sum_{\mathrm{i}} \mathrm{L}\left(\mathrm{C}_{\mathrm{i}}^{\mathrm{T}}, \mathrm{C}_{\mathrm{i}}^{\mathrm{t}}\right) \times \ln \left(\mathrm{ES}_{\mathrm{i}}^{\mathrm{T}} / \mathrm{ES}_{\mathrm{i}}^{\mathrm{t}}\right) \\
\Delta \mathrm{C}_{\text {efs }}=\sum_{\mathrm{i}} \mathrm{L}\left(\mathrm{C}_{\mathrm{i}}^{\mathrm{T}}, \mathrm{C}_{\mathrm{i}}^{\mathrm{t}}\right) \times \ln \left(\mathrm{EFS}^{\mathrm{T}} / \mathrm{EFS}^{\mathrm{t}}\right) \\
\Delta \mathrm{C}_{\text {et }}=\sum_{\mathrm{i}} \mathrm{L}\left(\mathrm{C}_{\mathrm{i}}^{\mathrm{T}}, \mathrm{C}_{\mathrm{i}}^{\mathrm{t}}\right) \times \ln \left(\mathrm{ET}^{\mathrm{T}} / \mathrm{ET}^{\mathrm{t}}\right) \\
\Delta \mathrm{C}_{\text {eli }}=\sum_{\mathrm{i}} \mathrm{L}\left(\mathrm{C}_{\mathrm{i}}^{\mathrm{T}}, \mathrm{C}_{\mathrm{i}}^{\mathrm{t}}\right) \times \ln \left(\mathrm{ELI}^{\mathrm{T}} / \mathrm{ELI}^{\mathrm{t}}\right) \\
\Delta \mathrm{C}_{\text {eag }}=\sum_{\mathrm{i}} \mathrm{L}\left(\mathrm{C}_{\mathrm{i}}^{\mathrm{T}}, \mathrm{C}_{\mathrm{i}}^{\mathrm{t}}\right) \times \ln \left(\mathrm{EAG}^{\mathrm{T}} / \mathrm{EAG}^{\mathrm{t}}\right) \\
\Delta \mathrm{C}_{\mathrm{pop}}=\sum_{\mathrm{i}} \mathrm{L}\left(\mathrm{C}_{\mathrm{i}}^{\mathrm{T}}, \mathrm{C}_{\mathrm{i}}^{\mathrm{t}}\right) \times \ln \left(\mathrm{POP}^{\mathrm{T}} / \mathrm{POP}^{\mathrm{t}}\right)
\end{gathered}
$$

In the above formulas, $\mathrm{L}()$ is called the logarithmic average function introduced by Ang to solve the Divisia decomposition, the specific formula is listed as:

$$
L\left(C_{i}^{T}, C_{i}^{t}\right)=\left\{\begin{array}{l}
\left(C_{i}^{T}-C_{i}^{t}\right) /\left(\ln C_{i}^{T}-\ln C_{i}^{t}\right), i f C_{i}^{T} \neq C_{i}^{t} \\
C_{i}^{t}, i f C_{i}^{T}=C_{i}^{t} \\
0, i f C_{i}^{T}=C_{i}^{t}=0
\end{array}\right.
$$

The contribution rate of each effect is defined as:

$\frac{\Delta \mathrm{C}_{\mathrm{es}}}{\Delta \mathrm{C}}+\frac{\Delta \mathrm{C}_{\mathrm{ge}}}{\Delta \mathrm{C}}+\frac{\Delta \mathrm{C}_{\mathrm{efs}}}{\Delta \mathrm{C}}+\frac{\Delta \mathrm{C}_{\mathrm{et}}}{\Delta \mathrm{C}}+\frac{\Delta \mathrm{C}_{\mathrm{eli}}}{\Delta \mathrm{C}}+\frac{\Delta \mathrm{C}_{\mathrm{eag}}}{\Delta \mathrm{C}}+\frac{\Delta \mathrm{C}_{\mathrm{pop}}}{\Delta \mathrm{C}}=100 \%$

\section{Tapio Decoupling Model}

Tapio put forward the definition of the decoupling elasticity index in a study on the transport industry in the European Union [38]. On the basis of the Tapio model, the corresponding variables conversion is demonstrated as follows:

$$
\varepsilon(\mathrm{C}, \mathrm{EAG})=\frac{\Delta \mathrm{C} / \mathrm{C}}{\Delta \mathrm{EAG} / \mathrm{EAG}}
$$

...where $\varepsilon(\mathrm{C}, \mathrm{EAG})$ stands for the decoupling elastic index, $\Delta \mathrm{C}$ for carbon emission variance from the power sector in a certain period, and $\triangle \mathrm{EAG}$ for the economic development variation in a certain period. In order to explore the contribution of each effect to the decoupling degree, Formula (5) is in conjunction with Formula (9) to obtain the decoupling indicators from the base year $t$ to the target year T: 


$$
\begin{gathered}
\varepsilon(\mathrm{C}, \mathrm{EAG})=\Delta \mathrm{C} \times \frac{\mathrm{EAG}}{\mathrm{C} \times \Delta \mathrm{EAG}} \\
=\left(\Delta \mathrm{C}_{\mathrm{es}}+\Delta \mathrm{C}_{\mathrm{ge}}+\Delta \mathrm{C}_{\mathrm{efs}}+\Delta \mathrm{C}_{\mathrm{et}}+\Delta \mathrm{C}_{\mathrm{eli}}+\Delta \mathrm{C}_{\mathrm{eag}}+\Delta \mathrm{C}_{\mathrm{pop}}\right) \times \frac{\mathrm{EAG}}{\mathrm{C} \times \Delta \mathrm{EAG}} \\
\varepsilon(\mathrm{C}, \mathrm{EAG})=\frac{\Delta \mathrm{C}_{\mathrm{es}} \times \mathrm{EAG}}{\mathrm{C} \times \Delta \mathrm{EAG}}+\frac{\Delta \mathrm{C}_{\mathrm{ge}} \times \mathrm{EAG}}{\mathrm{C} \times \Delta \mathrm{EAG}}+\frac{\Delta \mathrm{C}_{\mathrm{efs}} \times \mathrm{EAG}}{\mathrm{C} \times \Delta \mathrm{EAG}}+\frac{\Delta \mathrm{C}_{\mathrm{et}} \times \mathrm{EAG}}{\mathrm{C} \times \Delta \mathrm{EAG}}
\end{gathered}
$$

$$
\begin{aligned}
& +\frac{\Delta C_{\text {eli }} \times E A G}{C \times \Delta E A G}+\frac{\Delta C_{\text {eag }} \times E A G}{C \times \Delta E A G}+\frac{\Delta C_{\text {pop }} \times E A G}{C \times \Delta E A G} \\
= & T_{E S}+T_{G E}+T_{E F S}+T_{E T}+T_{E L I}+T_{E A G}+T_{P O P}
\end{aligned}
$$

In Formula (11), $\mathrm{T}_{\mathrm{ES}}, \mathrm{T}_{\mathrm{GE}}, \mathrm{T}_{\mathrm{EFS}}, \mathrm{T}_{\mathrm{ET}}, \mathrm{T}_{\mathrm{ELI}}, \mathrm{T}_{\mathrm{EAG}}$, and $\mathrm{T}_{\text {POP }}$ are impact decoupling indicators. The decoupling elastic index $\varepsilon$ of power-generated carbon emission and economic growth can thus be decomposed into fuel mix decoupling elastic $\mathrm{T}_{\mathrm{ES}}$, power generation efficiency decoupling elastic $\mathrm{T}_{\mathrm{GE}}$, power generation structure decoupling elastic $\mathrm{T}_{\mathrm{EFS}}$, power trade decoupling elastic $\mathrm{T}_{\mathrm{ET}}$, electricity intensity decoupling elastic $T_{E L I}$, economic activity decoupling elastic $T_{E A G}$, and demographic decoupling elastic $\mathrm{T}_{\mathrm{POP}}$. To avoid interpreting slight changes as significant, the variation of the elasticity value ranging from $\pm 20 \%$ around 1 (namely $0.8<$ elasticity value $<1.2$ ) is still regarded as coupling. In this way, as shown Fig. 1, eight conditions and corresponding boundaries can be obtained.

\section{Data Resources}

Since China has never published carbon emissions data for the power industry, those were calculated using fossil energy consumption data provided by the

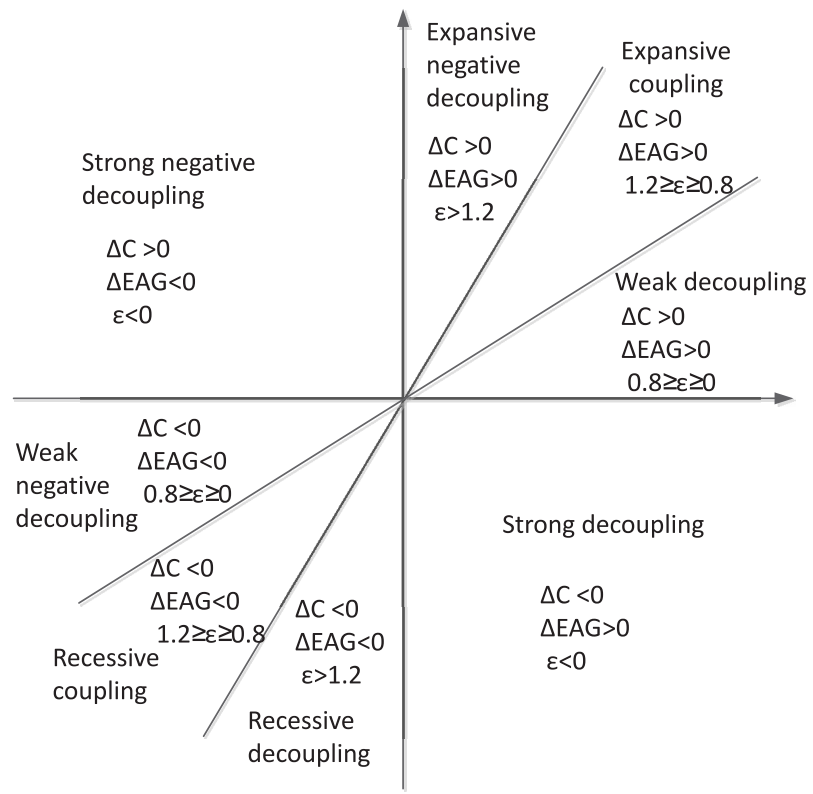

Fig. 1. The decoupling matrix between economic development and carbon emissions from electricity production.
National Energy Balance in the China Energy Statistics Yearbook. 1996 is the starting year with the latest data for 2016 as the end point. In the energy categories cited in this yearbook, the consumption figures of "Raw coal," "Cleaned coal," "Other washed coal," "Coke oven gas," "Crude oil," "Diesel oil," "Fuel oil," "Refinery gas," and "Natural gas" are selected. The remains are ignored due to lack of significance, such as "Blast furnace gas" and ambiguous composition such as "Other gases." The annual energy consumption is listed in Table 2. For the performance of LMDI model better, this paper classifies all considered energy into three types: "coal and its products," "oil and its products," and "gas and its products."

Using the average net heating value (Table 3) and carbon emission factor published by IPCC [39] (Table 4), the carbon emissions of the Chinese power industry can be received. This conversion method is widely employed in current research [40-41], proved to be more appropriate and correct. It should be noted that since the composition of "Other washed Coal" is not known, the mean value of "Middling" and "Peat" instead of the net heating value of "Other washed Coal." For the same reason, the "Oilfield gas" and "Gasfield gas" averages are used to calculate the "Natural Gas" net heating value. In addition, in order to calculate the power generation efficiency, the SCE conversion factor was also selected.

The electricity production and consumption figures also come from the China Energy Statistical Yearbook; the total GDP and population are obtained from the China Statistical Yearbook.

\section{Results and Discussion}

\section{Energy-Related $\mathrm{CO}_{2}$ of Power Output}

Fig. 2 shows the carbon emissions from China's electricity production in 1996-2016. The time slot of 1996 to 2016 represents carbon emissions from the power industry increasing from $1005.68 \mathrm{Mt}$ to $3671.1 \mathrm{Mt}$, with an average annual growth of $7.05 \%$. In view of the historical trends of $\mathrm{CO}_{2}$ emissions, it had undergone four stages: 1996-2000, 2000-2008, 2008-2013 and 2013-2016. From 1996 to 2000, there was no significant ascendant trend with a growth rate of $10.92 \%$. However, with the entrance into the second period, the absolute value of $\mathrm{CO}_{2}$ was rising promptly, having an increasing by $127.98 \%$. When it came to the third stage, it took only 6 years impressively to accumulate $1353.96 \mathrm{MtCO}_{2}$. Finally, the current had presented a U-shaped feature since 2013, which experienced volatility.

In order to facilitate calculating energy-related carbon emissions from electricity output and provide data support for future researchers, this paper reveals data on the carbon emission factor of electricity generation. From Fig. 3 it can be seen that the power carbon emission factor is generally in a declining state. 
Table 2. Annual energy consumption used for the power output in China.

\begin{tabular}{|c|c|c|c|c|c|c|c|c|c|}
\hline Year & $\begin{array}{l}\text { Raw } \\
\text { coal }\end{array}$ & $\begin{array}{c}\text { Cleaned } \\
\text { coal }\end{array}$ & $\begin{array}{l}\text { Other washed } \\
\text { coal }\end{array}$ & $\begin{array}{c}\text { Coke oven } \\
\text { gas }\end{array}$ & $\begin{array}{l}\text { Crude } \\
\text { oil }\end{array}$ & $\begin{array}{c}\text { Diesel } \\
\text { oil }\end{array}$ & $\begin{array}{c}\text { Fuel } \\
\text { oil }\end{array}$ & $\begin{array}{l}\text { Refinery } \\
\text { gas }\end{array}$ & $\begin{array}{c}\text { Natural } \\
\text { gas }\end{array}$ \\
\hline 1996 & 477.34 & 1.05 & 9.69 & 10.70 & 0.68 & 2.53 & 8.89 & 0.24 & 0.77 \\
\hline 1997 & 475.39 & 1.08 & 13.32 & 12.57 & 0.64 & 7.39 & 8.39 & 0.18 & 2.13 \\
\hline 1998 & 479.38 & 1.81 & 13.71 & 12.42 & 0.74 & 2.04 & 9.94 & 0.29 & 1.61 \\
\hline 1999 & 495.03 & 1.90 & 14.70 & 9.28 & 0.80 & 2.15 & 9.06 & 0.23 & 1.27 \\
\hline 2000 & 530.00 & 2.06 & 14.05 & 10.69 & 0.85 & 2.28 & 8.14 & 0.25 & 1.52 \\
\hline 2001 & 584.70 & 1.13 & 12.15 & 1.07 & 0.82 & 2.40 & 8.39 & 0.23 & 1.30 \\
\hline 2002 & 672.40 & 1.17 & 12.43 & 1.37 & 0.78 & 2.26 & 9.13 & 0.20 & 1.11 \\
\hline 2003 & 803.02 & 1.13 & 15.51 & 1.14 & 0.94 & 0.74 & 11.57 & 0.17 & 1.32 \\
\hline 2004 & 898.68 & 1.57 & 19.37 & 2.51 & 0.18 & 1.24 & 14.29 & 0.30 & 1.90 \\
\hline 2005 & 1017.09 & 0.86 & 18.68 & 3.74 & 0.41 & 0.82 & 10.69 & 0.43 & 3.01 \\
\hline 2006 & 1160.38 & 0.64 & 26.62 & 5.64 & 0.23 & 0.73 & 7.96 & 0.35 & 5.76 \\
\hline 2007 & 1246.63 & 0.26 & 32.29 & 7.95 & 0.16 & 0.66 & 5.66 & 0.38 & 8.07 \\
\hline 2008 & 1293.12 & 0.31 & 33.09 & 10.40 & 0.09 & 0.65 & 3.48 & 0.36 & 8.20 \\
\hline 2009 & 1406.13 & 0.17 & 33.37 & 8.84 & 0.04 & 0.44 & 1.93 & 0.51 & 13.42 \\
\hline 2010 & 1505.07 & 0.05 & 32.31 & 10.55 & 0.04 & 0.40 & 1.24 & 0.74 & 16.18 \\
\hline 2011 & 1728.67 & 0.53 & 26.59 & 11.86 & 0.11 & 0.39 & 0.61 & 0.72 & 19.78 \\
\hline 2012 & 1808.48 & 0.58 & 26.25 & 13.28 & 0.11 & 0.36 & 0.43 & 0.67 & 20.44 \\
\hline 2013 & 1925.34 & 0.56 & 25.88 & 15.28 & 0.10 & 0.36 & 0.47 & 0.60 & 21.87 \\
\hline 2014 & 1819.46 & 0.32 & 25.47 & 16.62 & 0.09 & 0.26 & 0.36 & 0.65 & 22.89 \\
\hline 2015 & 1766.44 & 0.32 & 26.43 & 16.96 & 0.12 & 0.22 & 0.31 & 0.50 & 29.16 \\
\hline 2016 & 1796.36 & 0.00 & 30.30 & 19.31 & 0.13 & 0.29 & 0.31 & 0.56 & 33.24 \\
\hline
\end{tabular}

Note: The unit of coke oven gas and natural gas is $10^{9}$ cubic meters, and the unit of remaining energy is Mt.

Table 3. Average net heating value and SCE conversion factor for different energy sources.

\begin{tabular}{|c|c|c|}
\hline Energy & $\begin{array}{c}\text { Average net heating } \\
\text { value factor }\end{array}$ & $\begin{array}{c}\text { SCE conversion } \\
\text { factor }\end{array}$ \\
\hline Raw coal & $20.908 \mathrm{GJ} / \mathrm{t}$ & $0.714 \mathrm{t} \mathrm{SCE} / \mathrm{t}$ \\
\hline $\begin{array}{c}\text { Cleaned } \\
\text { coal }\end{array}$ & $26.344 \mathrm{GJ} / \mathrm{t}$ & $0.900 \mathrm{t} \mathrm{SCE} / \mathrm{t}$ \\
\hline Middling & $8.363 \mathrm{GJ} / \mathrm{t}$ & $0.286 \mathrm{t} \mathrm{SCE} / \mathrm{t}$ \\
\hline Peat & $8.363-12.545 \mathrm{GJ} / \mathrm{t}$ & $0.286-0.429 \mathrm{t} \mathrm{SCE} / \mathrm{t}$ \\
\hline $\begin{array}{c}\text { Coke oven } \\
\text { gas }\end{array}$ & $16.726-17.981 \mathrm{MJ} / \mathrm{m}^{3}$ & $0.571-0.614 \mathrm{~kg} \mathrm{SCE} / \mathrm{m}^{3}$ \\
\hline Crude oil & $41.816 \mathrm{GJ} / \mathrm{t}$ & $1.429 \mathrm{t} \mathrm{SCE} / \mathrm{t}$ \\
\hline Diesel oil & $42.652 \mathrm{GJ} / \mathrm{t}$ & $1.457 \mathrm{t} \mathrm{SCE} / \mathrm{t}$ \\
\hline Fuel oil & $41.816 \mathrm{GJ} / \mathrm{t}$ & $1.429 \mathrm{t} \mathrm{SCE} / \mathrm{t}$ \\
\hline $\begin{array}{c}\text { Refinery } \\
\text { gas }\end{array}$ & $46.055 \mathrm{GJ} / \mathrm{t}$ & $1.571 \mathrm{t} \mathrm{SCE} / \mathrm{t}$ \\
\hline Oilfield gas & $38.931 \mathrm{MJ} / \mathrm{m}^{3}$ & $1.330 \mathrm{~kg} \mathrm{SCE} / \mathrm{m}^{3}$ \\
\hline Gasfield gas & $35.544 \mathrm{MJ} / \mathrm{m}^{3}$ & $1.214 \mathrm{~kg} \mathrm{SCE} / \mathrm{m}^{3}$ \\
\hline
\end{tabular}

The direct reason for this change is that the alteration of carbon emissions generated by the power output in one year is smaller than electricity produced. The indirect reason is the root of the direct cause, that is, producing the equivalent electricity consumes less energy than before. It can be further elaborated upon for improving energy efficiency and the adjusting fuel mix (change from intensive-carbon to low-carbon energy).

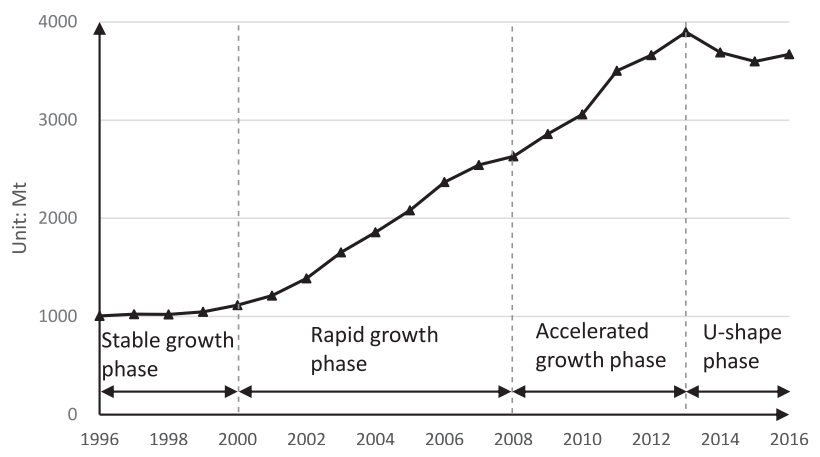

Fig. 2. $\mathrm{CO}_{2}$ emissions from the power industry in China. 
Table 4. Carbon emission factors for different energy sources.

\begin{tabular}{|c|c|c|c|c|c|c|c|}
\hline Energy & Coal & Coke oven gas & Crude oil & Diesel oil & Fuel oil & Refinery gas & Natural gas \\
\hline $\mathrm{CO}_{2}$ emission factor & 94.60 & 44.40 & 73.30 & 74.10 & 77.40 & 57.60 & 56.10 \\
\hline
\end{tabular}

Note: the unit is t/TJ and the carbon emission coefficients of raw coal, clean coal, and other clean coals are all 94.6t/TJ.

\section{LMDI Decomposition Analysis}

Aiming at observing and conducting a further study, the LMDI algorithm was performed annual decomposition and interval decomposition of $\mathrm{CO}_{2}$ from Chinese power generation in the study interval. Then based on the results obtained, those drivers are analyzed one by one concretely. The annual decomposition results are shown in Tables 5 and 6 . The interval decomposition results are shown in Fig. 4.

From the implemented results, we can see that the changes are connected with seven factors brought by LMDI. On the whole, the contribution of each driver varies. During the examined period, positive effects appear: economic activity effects, population effects and fuel mix effects. There are also negative drivers: power

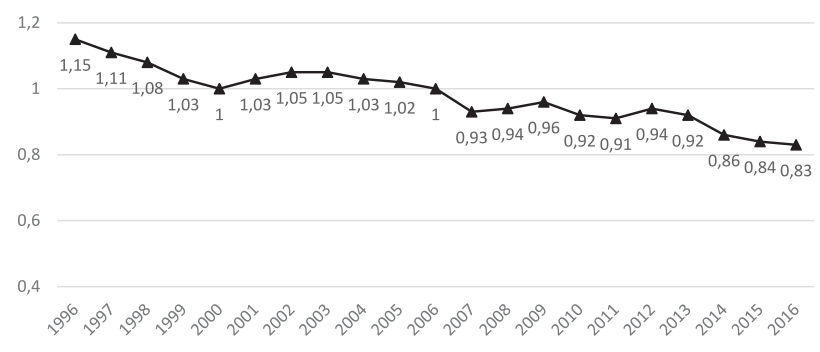

Fig. 3. Carbon emissions factors of power production during the study (the unit is $\mathrm{kg} / \mathrm{kWh}$ ).

generation efficiency effect, power generation structure effect, and electricity intensity effect.

Table 5. The annual LMDI decomposition of electricity $\mathrm{CO}_{2}$ emissions (contribution).

\begin{tabular}{|c|c|c|c|c|c|c|c|c|}
\hline Year & $\Delta \mathrm{C}_{\mathrm{es}}$ & $\Delta \mathrm{C}_{\mathrm{ge}}$ & $\Delta \mathrm{C}_{\mathrm{efs}}$ & $\Delta \mathrm{C}_{\mathrm{et}}$ & $\Delta \mathrm{C}_{\mathrm{eli}}$ & $\Delta \mathrm{C}_{\text {eag }}$ & $\Delta \mathrm{C}_{\mathrm{pop}}$ & $\Delta \mathrm{C}$ \\
\hline 1996-1997 & -4.82 & -27.99 & 1.35 & 9.75 & -61.03 & 98.67 & 10.20 & 26.13 \\
\hline $1997-1998$ & 3.38 & -38.34 & -5.30 & 12.01 & -37.99 & 53.70 & 9.34 & -3.21 \\
\hline 1998-1999 & 1.28 & -58.20 & 17.64 & 13.04 & -5.16 & 57.82 & 8.46 & 34.89 \\
\hline $1999-2000$ & 0.87 & -26.86 & -2.06 & 14.42 & -13.38 & 103.20 & 8.19 & 84.38 \\
\hline $2000-2001$ & 0.89 & 23.97 & -39.22 & 13.86 & -10.81 & 106.04 & 8.09 & 102.81 \\
\hline 2001-2002 & 1.37 & 17.73 & 12.77 & 13.30 & 18.46 & 118.36 & 8.38 & 190.36 \\
\hline $2002-2003$ & 0.94 & -1.14 & 45.86 & 12.75 & 29.49 & 181.09 & 9.11 & 278.10 \\
\hline 2003-2004 & -1.21 & -16.96 & -26.09 & 11.74 & -41.14 & 282.72 & 10.30 & 219.37 \\
\hline 2004-2005 & 2.83 & -36.76 & 9.39 & 10.42 & -29.53 & 267.23 & 11.59 & 235.17 \\
\hline $2005-2006$ & 0.40 & -36.04 & 21.66 & 10.92 & -59.89 & 351.37 & 11.72 & 300.15 \\
\hline 2006-2007 & -0.26 & -165.22 & 8.57 & 13.71 & -190.47 & 508.56 & 12.68 & 187.58 \\
\hline $2007-2008$ & 2.17 & 24.49 & -79.09 & 17.72 & -302.71 & 430.32 & 13.14 & 106.04 \\
\hline 2008-2009 & -4.44 & 47.33 & -6.15 & 18.56 & -30.18 & 207.79 & 13.35 & 246.26 \\
\hline $2009-2010$ & -1.85 & -124.50 & -40.83 & 18.77 & -122.08 & 475.55 & 14.17 & 219.23 \\
\hline $2010-2011$ & -0.71 & -14.09 & 87.57 & 19.69 & -164.89 & 522.77 & 15.69 & 466.04 \\
\hline 2011-2012 & 0.72 & 104.62 & -147.98 & 17.96 & -176.20 & 362.97 & 17.74 & 179.82 \\
\hline $2012-2013$ & 0.01 & -92.91 & 6.75 & 16.43 & -20.50 & 324.88 & 18.59 & 253.25 \\
\hline 2013-2014 & -3.06 & -222.03 & -129.91 & 15.43 & -184.50 & 314.31 & 19.74 & -190.02 \\
\hline 2014-2015 & -9.51 & -94.25 & -91.63 & 15.12 & -123.86 & 210.02 & 18.07 & -76.04 \\
\hline $2015-2016$ & -4.95 & -47.85 & -71.96 & 15.44 & -78.91 & 257.28 & 21.33 & 90.36 \\
\hline
\end{tabular}

Note: the unit is Mt. 
Table 6. The annual LMDI decomposition of electricity $\mathrm{CO}_{2}$ emissions (contribution rate).

\begin{tabular}{|c|c|c|c|c|c|c|c|c|}
\hline Year & $\Delta \mathrm{C}_{\mathrm{es}}$ & $\Delta \mathrm{C}_{\mathrm{ge}}$ & $\Delta \mathrm{C}_{\mathrm{efs}}$ & $\Delta \mathrm{C}_{\mathrm{et}}$ & $\Delta \mathrm{C}_{\mathrm{eli}}$ & $\Delta \mathrm{C}_{\text {eag }}$ & $\Delta \mathrm{C}_{\mathrm{pop}}$ & Summary \\
\hline 1996-1997 & -18.45 & -107.12 & 5.15 & 37.30 & -233.58 & 377.67 & 39.02 & 100.00 \\
\hline 1997-1998 & -105.34 & 1195.46 & 165.18 & -374.38 & 1184.55 & -1674.31 & -291.16 & 100.00 \\
\hline 1998-1999 & 3.68 & -166.82 & 50.56 & 37.39 & -14.79 & 165.74 & 24.25 & 100.00 \\
\hline $1999-2000$ & 1.03 & -31.83 & -2.44 & 17.09 & -15.86 & 122.30 & 9.71 & 100.00 \\
\hline $2000-2001$ & 0.87 & 23.31 & -38.15 & 13.48 & -10.52 & 103.13 & 7.87 & 100.00 \\
\hline 2001-2002 & 0.72 & 9.31 & 6.71 & 6.99 & 9.69 & 62.18 & 4.40 & 100.00 \\
\hline $2002-2003$ & 0.34 & -0.41 & 16.49 & 4.58 & 10.60 & 65.11 & 3.28 & 100.00 \\
\hline 2003-2004 & -0.55 & -7.73 & -11.89 & 5.35 & -18.75 & 128.88 & 4.69 & 100.00 \\
\hline 2004-2005 & 1.20 & -15.63 & 3.99 & 4.43 & -12.56 & 113.63 & 4.93 & 100.00 \\
\hline $2005-2006$ & 0.13 & -12.01 & 7.22 & 3.64 & -19.95 & 117.07 & 3.91 & 100.00 \\
\hline $2006-2007$ & -0.14 & -88.08 & 4.57 & 7.31 & -101.54 & 271.11 & 6.76 & 100.00 \\
\hline $2007-2008$ & 2.04 & 23.09 & -74.58 & 16.71 & -285.46 & 405.81 & 12.39 & 100.00 \\
\hline 2008-2009 & -1.80 & 19.22 & -2.50 & 7.54 & -12.26 & 84.38 & 5.42 & 100.00 \\
\hline 2009-2010 & -0.85 & -56.79 & -18.62 & 8.56 & -55.69 & 216.92 & 6.46 & 100.00 \\
\hline 2010-2011 & -0.15 & -3.02 & 18.79 & 4.22 & -35.38 & 112.17 & 3.37 & 100.00 \\
\hline 2011-2012 & 0.40 & 58.18 & -82.29 & 9.99 & -97.99 & 201.85 & 9.87 & 100.00 \\
\hline 2012-2013 & 0.00 & -36.69 & 2.67 & 6.49 & -8.10 & 128.28 & 7.34 & 100.00 \\
\hline $2013-2014$ & 1.61 & 116.85 & 68.37 & -8.12 & 97.09 & -165.41 & -10.39 & 100.00 \\
\hline 2014-2015 & 12.50 & 123.94 & 120.50 & -19.88 & 162.89 & -276.18 & -23.76 & 100.00 \\
\hline $2015-2016$ & -5.48 & -52.95 & -79.64 & 17.08 & -87.33 & 284.71 & 23.60 & 100.00 \\
\hline
\end{tabular}

Note: the unit is \%.

\section{Fuel Mix Effect}

The fuel mix effect cumulatively contributed $28.08 \mathrm{Mt}$ of carbon emissions within the timeframe of $1996-2016$, accounting for $1.15 \%$ of the total change. In light of the annual decomposition results, the fuel mix effect is in a fluctuating state, but the effect value in the past three years is negative. This may be related to

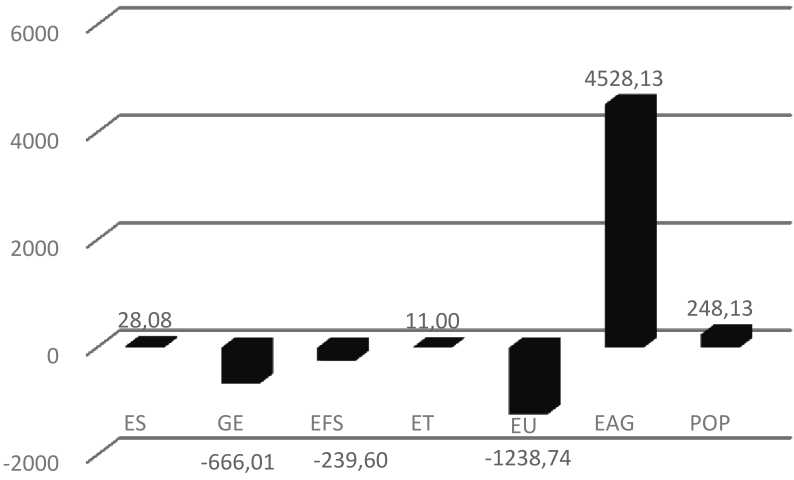

Fig. 4. Electricity carbon emissions LMDI decomposition results in 1996-2016 (unit: Mt). the changing trend of energy consumption and the shift toward cleaner fuel resources. A detailed and classified energy use structure is displayed in Fig. 5.

Replacing partial coal and oil with natural gas: The proportion of natural gas used has ramped up year by year, from $0.27 \%$ in 1996 to $3.13 \%$ in 2016; in contrast, the percentage of coal and oil and their products is falling. Under the background of the shortage of oil resources in China, the oil consumed units are shifting to coal-fired units and gas-fired units. Combusted coal and natural gas and their products in absolute value had to step up in order to maintain a sufficient supply of electricity, especially after 2008.

The dominance of coal and its products: despite being influenced by national policies, coal cleanliness is advocated and cleaner energy is instead of coal to a certain extent. However, due to resource endowment, coal and its accessories have always dominated fuel for power generation. Although its proportion fluctuates, the value never falls below $90 \%$. This explains that the fuel mix effect yearly during the study is not stable, but it is a positive driver in the overall time. In addition, advisably, the increasing natural gas usage and the booming development of gas-fired power generation 


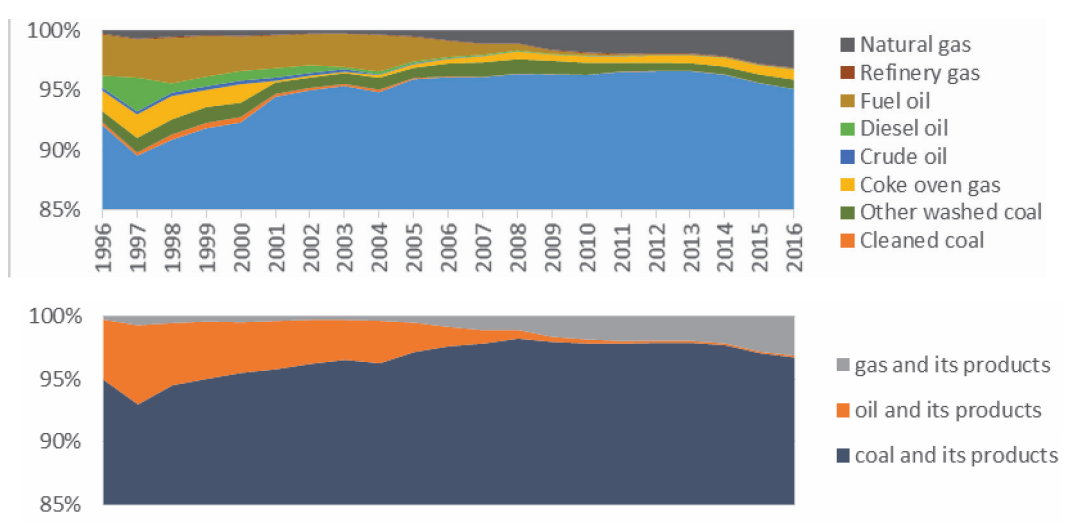

Fig. 5. The specific and classified energy use structure in the power sector.

provide the possibility for reducing carbon emissions in the power industry in the future.

\section{Power Generation Efficiency Effect}

Power generation efficiency is deemed as the ratio of energy consumption to power generation, also called energy conversion efficiency. The accumulated effect in period-wise is a decrease of $666.01 \mathrm{Mt}$ - the total effect of $-24.93 \%$. From a yearly perspective, apart from the interval time affected by economic activity, power generation efficiency is the suppressing driver in carbon emissions from the power industry. The change of thermal power generation efficiency can be attributed to two aspects: technology and management [7].

Technical improvement: In the short term, there is little correlation between electricity production and technology levels. However, from long-term consideration, the future construction of the power industry will definitely tend to apply energy-saving technologies, accompanied by the more efficient transition such as integrated gasification combined cycle (IGCC) and combined cooling heating and power (CCHP). Undoubtedly, the application of emerging technologies will reduce the energy-consumed level of unit power generation, which in turn push more electricity in equal resources.
Management improvements: with the normalization of the power market environment, particularly competitive electricity price bidding, response mechanisms between a change in power consumption and the change in power generation efficiency can be established. When electricity demand declines, the dispatch department would be intend to give prioritized share of generation to power plants with higher efficiency to reduce costs, because the power demand can be met even with shutting down old inefficient plants. Therefore, during the period of the $12^{\text {th }}$ FiveYear Plan (2011-2015), the closure number of small thermal power units with high pollution and high consumption reached $2800 \mathrm{~kW}$ under a necessary precondition of sufficient power. In such a case, the power generation efficiency of the total industry is improved.

\section{Electricity Production Structure Effect}

Our results reveal that electricity production structure effect provides an impetus to cutting carbon emissions and its contribution degree is $-8.97 \%$ in 1996-2016. From the annual decomposition results, the power generation structure effects can be roughly divided into two phases: 1996-2011, 2011-2016. The specific electricity generated from thermal power,

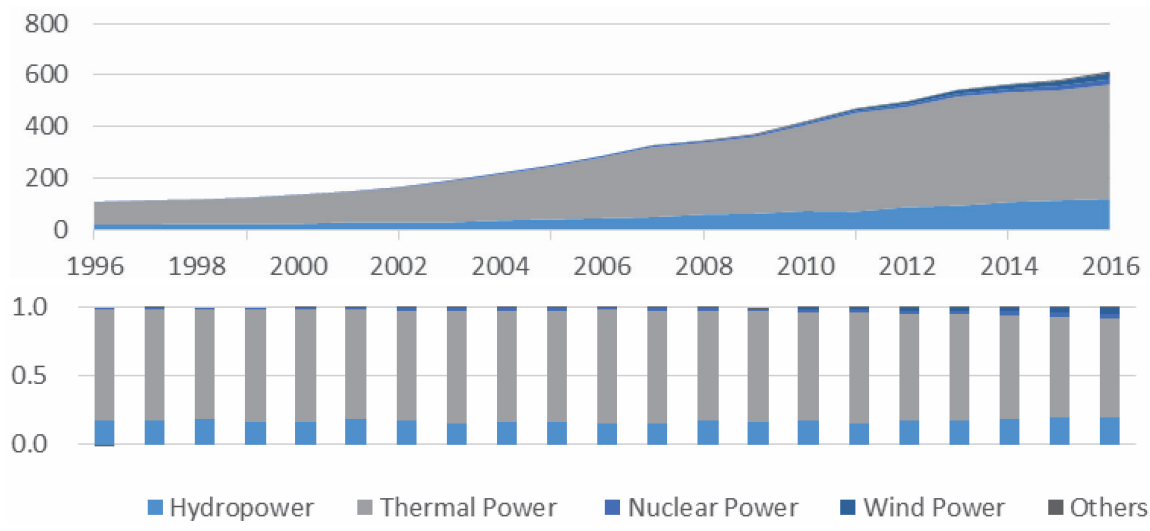

Fig. 6. Power generation in absolute value (unit: Mt) and relative value. 
hydropower, nuclear power, wind power and other (solar energy, biomass, etc.) is shown in Fig. 6.

The first period: The power generation structure effect is disordered in 1996-2011. Sometimes the effect is regarded as a factor that stimulates the increase of carbon emissions and as a restraining driver in remaining times. This indicates that the quantitative relationship between thermal power generation and other non-fossil energy generation is unstable, although total power generation is rising during this period (Fig. 6), which caused a sudden change in the effect.

The second period: The interval time of 2011-2016 includes the $12^{\text {th }}$ Five-Year Plan and the first year of the $13^{\text {th }}$ Five-Year Plan. The fuel mix effect during this period is an inhibiting factor for carbon emissions except for 2012-2013. During the $12^{\text {th }}$ Five-Year Plan period, the Chinese government promulgated a series of drastic policies to optimize power structure such as the "Emission standard of air pollutants for thermal power plants 2011" and "Notice of the State Council on printing and distributing air pollution control action plan 2013," which effectively support the development of non-fossil fuel generation and adjust the proportion of thermal power generation.

However, the positive effect $\left(\Delta \mathrm{C}_{\mathrm{efs}}\right)$ in 2012-2013 can be explained by unusual changes in non-thermal power generation. In 2011, a magnitude 9.0 earthquake caused a serious leakage of radioactive materials at the Fukushima nuclear power plant, raising concerns about nuclear safety in China. For security reasons, the Chinese government suspended the approval of new nuclear power projects and conducted a comprehensive inspection for all nuclear power plants in operation and under construction. These policies hindered the development of nuclear power [42]. In addition, drought attacked a partial region in China, causing the hydropower output to be less than expectations and abnormal fossil energy consumption in the thermal power industry.

\section{Electricity Trade Effect}

Whether it is the annual decomposition result or the interval decomposition result, the effect $\left(\Delta \mathrm{C}_{\mathrm{et}}\right)$ is always positive, having a total contribution of $11 \mathrm{Mt}$. The variation on the proportion of electricity production and electricity consumption bring about power trade effects. The reason for the unequal power production and consumption is the electric import and export between countries, that is, the regional diversion of power. When the power import is greater than the power export, power consumption is more than power production; conversely, power consumption is less than production. Electricity production has always been greater than consumption, hence the ratio of electricity generation to power consumption has remained above 1.0 .

As illustrated in Fig. 7, China's electricity imports and exports were both in a fluctuating increase over the period of 1996 to 2016. Compared by imported power, export had a dramatic increase from 35.9 million $\mathrm{kWh}$ in 1996 to 127.2 million $\mathrm{kWh}$ in 2016. For a country dominated by fossil fuel like China, more electricity exports would mean greater local emissions, overshadowing the positive effects of power importing. Therefore, the viewpoint of this article is similar to the previous literature. Countries can turn to more imported power appropriately, helping implement national decarburization strategy in a cost-effective manner [43]. However, from a global perspective, global reductions engaged in power industry only are possible if the emission intensity of the exporting country is less than the importing country.

\section{Electricity Intensity Effect}

Power intensity effect plays the most important role in controlling the increase in carbon emissions, which is in line with previous research [14-15]. The accumulated effect $\left(\Delta \mathrm{C}_{\mathrm{et}}\right)$ displaced $1238.74 \mathrm{Mt}$ $\mathrm{CO}_{2}$ from China's atmosphere with a contribution rate of $-46.38 \%$. The electricity intensity is defined as the consumed electricity per unit of GDP. The specific changes are shown in Fig. 8. Obviously, the curve of the power intensity decreases on the whole but can be roughly divided into two period: 1996-2003, 2003-2016.

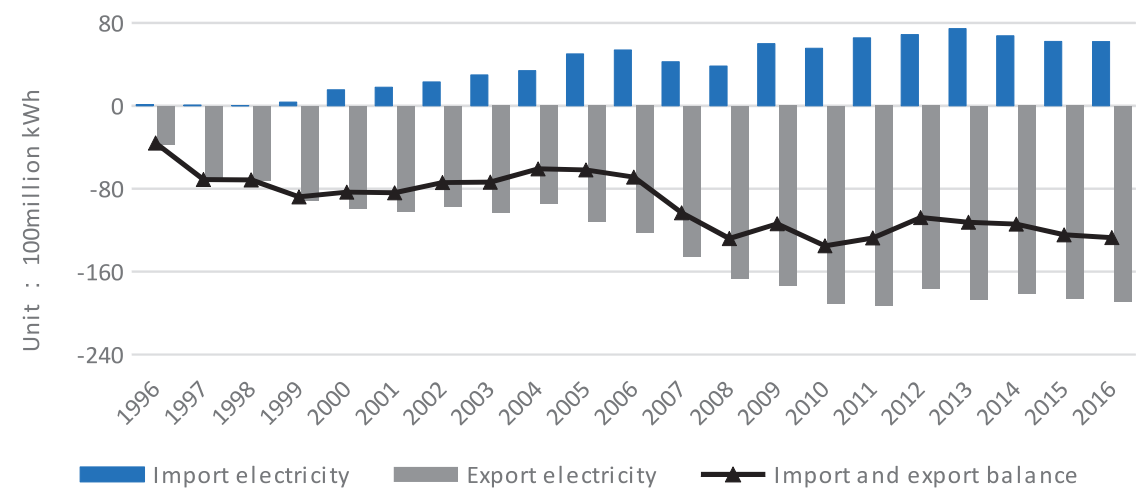

Fig. 7. Comparison of China's import electricity and export electricity. 


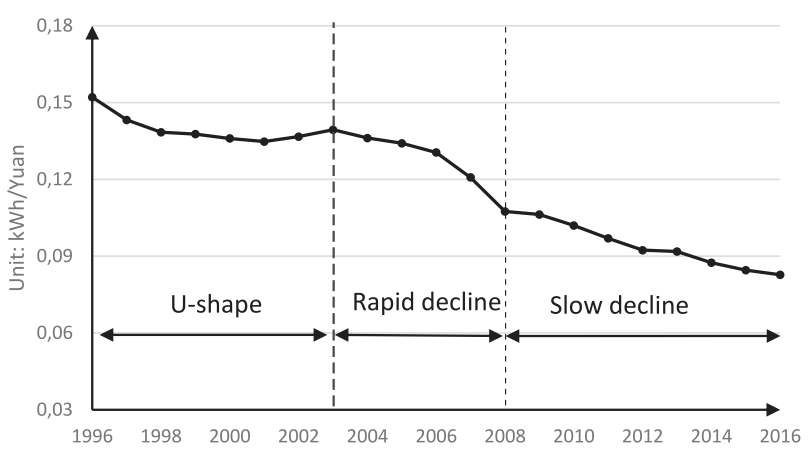

Fig. 8. The trajectory of electricity intensity.

In the first phase, the change in power intensity seems to appear in a cyclic pattern showing a U-shaped curve. It is suggested that there is a lag between a reduction in GDP growth and a corresponding reduction in electricity production [37]. The second phase is characterized by continuous decline, which is divided into the rapid decline phase of 2003-2008 and the slow decline phase of 2008-2016. The drop in electricity intensity means the extension of higher efficiency, and its inhibition manifests in the application of new technologies, new equipment and new management concepts. As the most significant carbon reduction factor, it can be expected that in the future inhibitory action of the electricity intensity effect will exist continuously, but it may decline to a certain extent due to technical bottlenecks and the difficulties in the implementation of management measures.

\section{Economic Activity Effect}

Our research conveys a message that the economic activity effect is the main promoter to carbon emissions in the power industry whether it is the interval decomposition or the annual decomposition. The accumulated effect is an increase of $4528.13 \mathrm{Mt}$, which accounts for $169.53 \%$ of the total change. There is a stable equilibrium link between economic development and power consumption. Economic activity depends on the strong support of electricity consumption that determines the production of electricity conversely. From the perspective of development, China's industrialization and urbanization process requires a large amount of electricity as a driving force, and has been proven to have a great impact on the carbon emissions performance of the power industry [16].

Observing the contribution value of the annual economic activity effect, it is positive but not always rising. Due to the broken Asian financial crisis in 1997 and the global financial crisis in 2008, the dynamic economic activities were slightly affected. The contribution of economic activity effect had decreased after 1997-1999, 2008-2009. Despite this, carbon emissions from the power industry have not declined. Table 6 sends the message that power generation efficiency effect was changed from promotion to suppression. On the basis of China's power generation dispatching, hydropower and nuclear power have priority to access the power grid. While economic activity is weakening, thermal power utilization hours continue to decline, resulting in a significant reduction in energy system efficiency and a waste of resources.

After 2012, owing to a major change in domestic and overseas environments, the Chinese economy has entered a "new normal," slowing the pace and shifting from high-speed growth to medium-high speed growth. Hence, the contribution after 2012 is going down. In this moment, economic activity still plays a dominant role. Control vigor over the power industry policy by state is undiminished and focuses on the allocation of resources. The effects of fuel mix, power generation efficiency, power generation structure and power intensity are all in a suppressed state, alleviating the rising trajectory of $\mathrm{CO}_{2}$ to a large extent.

\section{Population Size Effect}

The population size effect is the second largest positive driver of carbon emissions, besides economic activity effect. It contributed $248.13 \mathrm{Mt} \mathrm{CO}_{2}$ from interval decomposition outcome. First of all, with the improvement of the living standards for residents, the demand for electricity has been stimulated and electrification has popularized the use of household appliances, which make the average electricity consumption for residents increase from $87 \mathrm{kWh}$ in 1996 to $443 \mathrm{kWh}$ in 2016. Second, other consumer behaviors except for electricity consumption which increase the requirement of daily necessities, indirectly motivate the electricity demand of the manufacturing industry. In addition, China is a populous country, and the large base makes the growth rate only about $1 \%$, but the average growth rate of electricity consumption is as high as $9.3 \%$. It can be predicted that the universal two-child policy would further encourage the ascent in population scale effect.

\section{Analysis of Decoupling Elastic Indicators}

\section{Impact Indicator Analysis}

In order to conduct further research and analysis on the decoupling status between economic activity and $\mathrm{CO}_{2}$ from power output, after the decomposition, we came to the field of Tapio model. Explaining the causes of the decoupling status in detail can benefit from the combination of Tapio algorithm with the LMDI model. Table 7 shows the decoupling elasticity value and corresponding decoupling status, and the influence of drivers in different directions on the decoupling process from 1996 to 2016. The final results listed in Table 7 expound that weak decoupling and expansive decoupling are common conditions, that is, economic development spurs $\mathrm{CO}_{2}$ engaged in power generation. 
Table 7. Annual results of $\varepsilon(\mathrm{C}, \mathrm{EAG})$, decoupling status and its factors.

\begin{tabular}{|c|c|c|c|c|c|c|c|c|c|}
\hline Year & $\mathrm{T}_{\mathrm{ES}}$ & $\mathrm{T}_{\mathrm{GE}}$ & $\mathrm{T}_{\mathrm{EFS}}$ & $\mathrm{T}_{\mathrm{ET}}$ & $\mathrm{T}_{\mathrm{ELI}}$ & $\mathrm{T}_{\mathrm{ELI}}$ & $\mathrm{T}_{\mathrm{POP}}$ & $\varepsilon(\mathrm{C}, \mathrm{EAG})$ & Decoupling states \\
\hline 1997 & -0.05 & -0.29 & 0.01 & 0.10 & -0.64 & 1.04 & 0.11 & 0.28 & Weak decoupling \\
\hline 1998 & 0.06 & -0.73 & -0.10 & 0.23 & -0.73 & 1.03 & 0.18 & -0.06 & Strong decoupling \\
\hline 1999 & 0.02 & -1.02 & 0.31 & 0.23 & -0.09 & 1.02 & 0.15 & 0.61 & Weak decoupling \\
\hline 2000 & 0.01 & -0.26 & -0.02 & 0.14 & -0.13 & 1.02 & 0.08 & 0.83 & Expansive negative decoupling \\
\hline 2001 & 0.01 & 0.23 & -0.37 & 0.13 & -0.10 & 1.00 & 0.08 & 0.97 & Expansive negative decoupling \\
\hline 2002 & 0.01 & 0.15 & 0.11 & 0.11 & 0.15 & 0.98 & 0.07 & 1.57 & Expansive negative decoupling \\
\hline 2003 & 0.01 & -0.01 & 0.25 & 0.07 & 0.16 & 0.97 & 0.05 & 1.49 & Expansive negative decoupling \\
\hline 2004 & 0.00 & -0.06 & -0.09 & 0.04 & -0.15 & 1.02 & 0.04 & 0.79 & Weak decoupling \\
\hline 2005 & 0.01 & -0.14 & 0.04 & 0.04 & -0.11 & 1.01 & 0.04 & 0.89 & Expansive negative decoupling \\
\hline 2006 & 0.00 & -0.10 & 0.06 & 0.03 & -0.17 & 1.01 & 0.03 & 0.87 & Expansive negative decoupling \\
\hline 2007 & 0.00 & -0.35 & 0.02 & 0.03 & -0.40 & 1.07 & 0.03 & 0.39 & Weak decoupling \\
\hline 2008 & 0.01 & 0.06 & -0.20 & 0.04 & -0.75 & 1.07 & 0.03 & 0.26 & Weak decoupling \\
\hline 2009 & -0.02 & 0.23 & -0.03 & 0.09 & -0.14 & 1.00 & 0.06 & 1.18 & Expansive negative decoupling \\
\hline 2010 & 0.00 & -0.27 & -0.09 & 0.04 & -0.27 & 1.05 & 0.03 & 0.48 & Weak decoupling \\
\hline 2011 & 0.00 & -0.03 & 0.17 & 0.04 & -0.32 & 1.01 & 0.03 & 0.90 & Expansive negative decoupling \\
\hline 2012 & 0.00 & 0.30 & -0.42 & 0.05 & -0.50 & 1.03 & 0.05 & 0.51 & Weak decoupling \\
\hline 2013 & 0.00 & -0.29 & 0.02 & 0.05 & -0.06 & 1.01 & 0.06 & 0.79 & Weak decoupling \\
\hline 2014 & -0.01 & -0.76 & -0.44 & 0.05 & -0.63 & 1.07 & 0.07 & -0.65 & Strong decoupling \\
\hline 2015 & -0.05 & -0.47 & -0.45 & 0.08 & -0.61 & 1.04 & 0.09 & -0.38 & Strong decoupling \\
\hline 2016 & -0.02 & -0.19 & -0.29 & 0.06 & -0.31 & 1.03 & 0.09 & 0.36 & Weak decoupling \\
\hline
\end{tabular}

Strong decoupling states have only appeared in 1998, 2014 and 2015.

According to Formula (11), the decoupling elasticity value is quantitatively decomposed into $\mathrm{T}_{\mathrm{ES}}, \mathrm{T}_{\mathrm{GE}}, \mathrm{T}_{\mathrm{EFS}}$, $\mathrm{T}_{\mathrm{ET}}, \mathrm{T}_{\mathrm{ELI}}, \mathrm{T}_{\mathrm{EAG}}$ and $\mathrm{T}_{\mathrm{POP}}$ to evaluate the critical factors affecting the decoupling state. The data in Table 7 deliver a message that the power generation efficiency effect, electricity generation structure effect, and electricity intensity effect play a positive role in the uncoupling process, but they are not immutable during the examined period as seen in annual decomposed outcomes. Contrasted with the effect of power generation efficiency and electricity generation structure, electric energy intensity effect performs quit distinguished in reducing carbon emissions, especially to strong decoupling in 1998, 2014, and 2015. Like decomposition analysis, this phenomenon may be attributed to the improved efficiency of the entire power industry and the support of national policies, which is crucial for the achievement of powerful decoupling targets.

\section{Trend Analysis}

In early 2003, China implemented a market-oriented reform to the power industry and formulated a reform policy of "separation of plant and grid, price bidding for use of grid." The main content of this reform is that it introduced competitive mechanisms between power plants aiming to improve their generating efficiencies. Before the reform, all elements of power industry in China (power generation, transmission and distribution) were "vertically integrated" [44]. After the reform, the vertically integrated management system was abolished, and all power plants were given equal rights to access the power grid through competition. Furthermore, renewable energies, especially wind power and photovoltaic power, were developed in the following years in order to reduce the share of fossil energy consumption [45]. As a consequence, 2003 was set as the time demarcation line to explore the effectiveness of electric reform to the decoupling tend of carbon emissions and economic development.

In order to demonstrate the development trend of the $\varepsilon(C, E A G)$ before and after the electric reform, the ordinary least-squares method is used to obtain the twostage linear equations:

$$
\varepsilon(\mathrm{C}, \mathrm{EAG})=-519.89+0.26 \mathrm{x} \quad \mathrm{x} \in[1996,2003]
$$

$\varepsilon(\mathrm{C}, \mathrm{EAG})=150.54-0.075 \mathrm{x} \quad \mathrm{x} \in[2004,2016]$ 


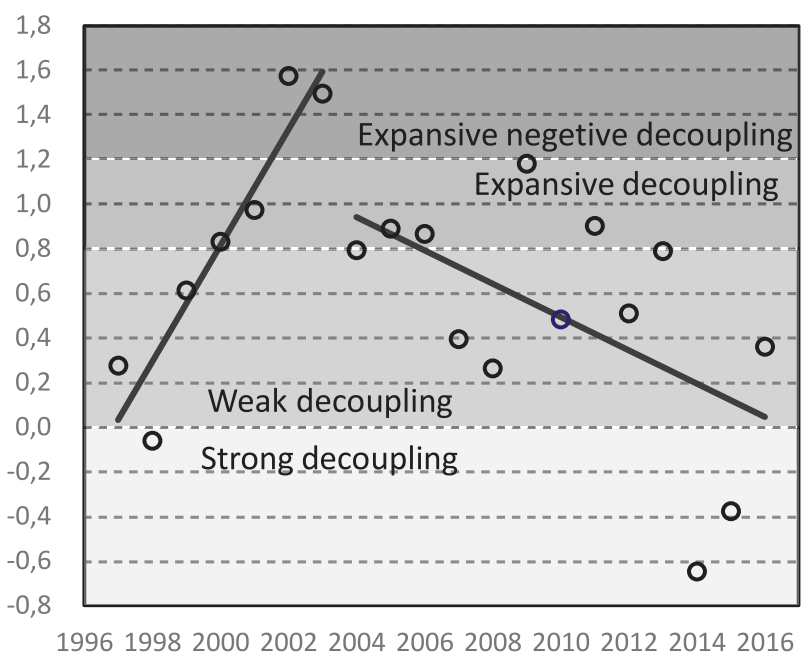

Fig. 9. Classification, fitting results of $\varepsilon(C, E A G)$.

The distribution, classification and linear fitting results of $\varepsilon(C, E A G)$ before and after the electric reform are displayed in Fig. 9 in order to analyze the current of decoupling extent. As presented in Fig. 9, the curve before the reform shows an upward trend, while the fitted curve after the reform is in a slightly downward trend. Therefore, market-oriented reforms in 2003 have changed the developmental trend of the decoupling power carbon emissions from economic development, and proved the correctness about the introduction of generation-side competition mechanisms. Shang et al. analyzed the link between $\mathrm{CO}_{2}$ from the power industry and total carbon emissions before and after the reform in 2003, and also reached the same conclusion, namely that competition among power plants is effective [46].

In 2016, China opened up the power supply-side market, a promising reform, to further advance the process of decoupling energy-related carbon emissions from economic development. Considering that the power sector is the single most important carbon emitter for the country, a future trend may help realize the commitment that China would reach its carbon emission peak by 2030 [30].

\section{Conclusions}

\section{Major Conclusions}

The electric power industry, as a major emitter in China and even in the world, needs to be given priority by policy makers. In order to identify whether power industry in China is on the way of transforming to a low-carbon development, the following work has been done:

First, we conducted our analysis on the basis of the historical trajectory of energy-related $\mathrm{CO}_{2}$ from electricity output. Second, we used the LMDI method with outstanding advantages to obtain the annual and interval drivers. Third, we employed a novel decoupling elastic index as a means to probe the link between the carbon emissions caused by electrical output and economic development. Furthermore, we did the work that decoupling elastic index was decomposed into seven indicators based on the LMDI approach. Finally, we explored the decoupling trend before and after the electric market reform. We came to the conclusions as follows:

(1) Growth and volatility are the key features of the aggregate carbon emissions in the power industry, which was divided into 1996-2000 (stable growth phase), 2000-2008 (rapid growth state), 2008-2013 (accelerated growth phase), and 2013-2016 (U-shape phase). The ever-declining carbon emission factor of electricity production indicates that the power sector has made gradual progress in reducing emissions.

(2) The interval decomposition results reflect the comprehensive condition. The positive driving factors are economic activity effect (169.53\%), population scale effect $(9.29 \%)$, fuel mix structure effect $(0.41 \%)$, and electricity trade effect $(1.05 \%)$; the negative driving factors are electricity intensity effect (-46.38\%), power generation efficiency effect $(-24.93 \%)$, and power generation structure effect $(-8.97 \%)$. The annual decomposition demonstrates that economic activity, population size, and power trade always promote the increase of carbon emissions, and the remains were not immutable. The electricity intensity effect proved to be the overwhelming contributor to suppressing $\mathrm{CO}_{2}$ emission increases. Technological progress still exists.

(3) In light of the decoupling elastic index, weak decoupling and expansive decoupling are the main characteristic states during our study period. Strong decoupling only occurred in 1998, 2014, and 2015, indicating that carbon reduction efforts are more powerful. Electricity intensity effect is the main force to promote the decoupling process.

(4) The market-oriented reforms in 2003 led the developmental trend of the decoupling elastic index from upward to downward. As expected, the current development direction of the decoupling index is a strong decoupling.

\section{Policy Implications}

Based on the above empirical findings, we give corresponding recommendations to make efforts for promoting a low-carbon process.

(1) Technological progress is a precursor to the lowcarbon development for China's power industry.

Due to resource endowments and historical development in China, coal is the foundation of power generation sources. Therefore, clean coal technology is one of the major technologies for solving environmental problems such as the ultrasupercritical (USC) units and the circulating fluidized bed (CFB), which should be promoted to construct thermal power 
plants or upgrade power equipment in the future. Moreover, the power supply must be diversified. By increasing the share of wind power, solar resources, and hydropower and biomass energy, clean renewable energy can be accelerated to utilize the premise of ensuring safety. The next step is to strengthen the acceptance and absorption of non-thermal power during grid construction.

The smart grid is a necessary technology for achieving win-win between the power supply-side and the private user. It establishes an interactive platform to communicate with each other, further realizing demand side management. Based on this, smart grids can select high-quality power for consumers based on their needs and available electrical energy information. Additionally, the smart grid offers efficient power management to avoid transmission and distribution losses as much as possible. In brief, the smart grid is a promising measure to further minimize carbon emissions from electricity.

(2) Policy support is the basic guarantee for the lowcarbon transition in China's power industry.

The management role for government is indispensable in the power sector. The empirical analysis has proved that the competition mechanism on the power generation-side has successfully changed the direction of the developmental decoupling index while the reform in 2016 about the power supply-side proposed by the government is still in progress. The market-oriented reform in electricity industry ought to persist, and more and more market players should be encouraged to participate in competition for electricity sales.

In addition, the annual effect of the power generation structure is unstable due to fluctuations in the proportion of thermal power generation. Hence, the government should strengthen more strict supervision and guidance on investment in the construction of thermal power plants.

(3) Guiding residents to a low-carbon lifestyle is also an effective means.

Due to the aging population, carbon emissions cannot be suppressed by strictly controlling population growth. Therefore, it is a good choice to guide residents on low-carbon life, such as encouraging low-carbon travel by public transport or shared bicycles. Moreover, in the process of urbanization, special attention should focus on the electricity load changes caused by rural populations transferring to cities, as well as the medium/ long-term forecasts.

\section{Acknowledgements}

The sources of funding of the study were Hebei Province Social Science Fund (HB15YJ038), Hebei Province Soft Science Foundation (16454302D) and the Central College Fund of North China Electric Power University (2014MS150).

\section{Conflict of Interest}

The authors declare no conflict of interest.

\section{References}

1. AGHAHOSSEINI A., BOGDANOV D., GHORBANI N., BREYER C. Analysis of $100 \%$ renewable energy for Iran in 2030: integrating solar PV, wind energy and storage. International Journal of Environmental Science and Technology, 15 (1), 17, 2018.

2. SUN W., XU Y. Using a back propagation neural network based on improved particle swarm optimization to study the influential factors of carbon dioxide emissions in Hebei Province, China. Journal of Cleaner Production, 112, 1282 , 2016.

3. SMOL J.P. Climate Change: A planet in flux. Nature, $\mathbf{4 8 3}$ (7387), S12, 2012.

4. Statistical Review of World Energy 2015. Available online: www.bp.com/statisticalreview (accessed on 27 March 2018)

5. GAO Y., CHENG H., ZHU J., LIANG H., LI P. The Optimal Dispatch of a Power System Containing Virtual Power Plants under Fog and Haze Weather. Sustainability, 8 (1), 71, 2016.

6. XIAOYE Z., JUNYING S., YAQIANG W., WEIJUN L., QIANG Z., WEIGANG W., JIANNONG Q., GUOLIANG C., JIZHI W., YUANQIN Y., YANGMEI Z. Factors contributing to haze and fog in China. Chinese Science Bulletin, 58 (13), 1178, 2013.

7. MENG M., JING K., MANDER S. Scenario analysis of $\mathrm{CO}_{2}$ emissions from China's electric power industry. Journal of Cleaner Production, 142, 3101, 2017.

8. National Bureau of Statistics. China Energy Statistical Yearbook; China Statistics Press: Beijing, 96-101, China, 2017 [In Chinese].

9. WANG Q., JIANG X., LI R. Comparative decoupling analysis of energy-related carbon emission from electric output of electricity sector in Shandong Province, China. Energy, 127, 78, 2017.

10. LIU N., MA Z., KANG J. A regional analysis of carbon intensities of electricity generation in China. Energy Economics, 67, 268, 2017.

11. SUN W., HE Y., GAO H. An Electric Carbon Productivity Analysis of China's Industrial Sector Using Multi-Dimensional Decomposition. Polish Journal of Environmental Studies, 25 (4), 1699, 2016.

12. JIANG X., LI R. Decoupling and Decomposition Analysis of Carbon Emissions from Electric Output in the United States. Sustainability, 9 (6), 886, 2017.

13. SUN W., HE Y., CHANG H. Regional characteristics of $\mathrm{CO}_{2}$ emissions from China's power generation: affinity propagation and refined Laspeyres decomposition. International Journal of Global Warming, 11 (1), 38, 2017.

14. ZHOU J., GUANG F., DU S. Decomposing the Decoupling of Carbon Emissions and Economic Growth in China's Power Industry. Polish Journal of Environmental Studies, 26 (5), 2407, 2017.

15. ZHANG C., ZHANG M., ZHANG N. CO2 Emissions from the Power Industry in the China's Beijing-TianjinHebei Region: Decomposition and Policy Analysis. Polish Journal of Environmental Studies, 26 (2), 903, 2017.

16. YAN D., LEI Y., LI L. Driving Factor Analysis of Carbon Emissions in China's Power Sector for Low-Carbon 
Economy. Mathematical Problems in Engineering, 2017, 1, 2017.

17. KARMELLOS M., KOPIDOU D., DIAKOULAKI D. A decomposition analysis of the driving factors of $\mathrm{CO}_{2}$ (Carbon dioxide) emissions from the power sector in the European Union countries. Energy, 94, 680, 2016.

18. NOORPOOR A.R., KUDAHI S.N. $\mathrm{CO}_{2}$ emissions from Iran's power sector and analysis of the influencing factors using the stochastic impacts by regression on population, affluence and technology (STIRPAT) model. Carbon Management, 6 (3-4), 101, 2015.

19. STEENHOF P.A., WEBER C.J. An assessment of factors impacting Canada's electricity sector's GHG emissions. Energy Policy, 39 (7), 4089, 2011.

20. ANG B.W., SU B. Carbon emission intensity in electricity production: A global analysis. Energy Policy, 94, 56, 2016.

21. ANG B.W., GOH T. Carbon intensity of electricity in ASEAN: Drivers, performance and outlook. Energy Policy, 98, 170, 2016.

22. CHEN G., HOU F., CHANG K. Regional decomposition analysis of electric carbon productivity from the perspective of production and consumption in China. Environmental Science and Pollution Research, 25 (2), $1508,2018$.

23. ANG B.W. LMDI decomposition approach: A guide for implementation. Energy Policy, 86, 233, 2015.

24. ANG B.W. Decomposition analysis for policymaking in energy. Energy Policy, 32 (9), 1131, 2004.

25. KRAFT J., KRAFT A. On the relationship between energy and GNP. Energy, 3 (2), 401, 1978.

26. ZHANG Q., LIAO H., HAO Y. Does one path fit all? An empirical study on the relationship between energy consumption and economic development for individual Chinese provinces. Energy, 150, 527, 2018.

27. APPIAH M.O. Investigating the multivariate Granger causality between energy consumption, economic growth and $\mathrm{CO}_{2}$ emissions in Ghana. Energy Policy, 112, 198, 2018.

28. LU W. Greenhouse Gas Emissions, Energy Consumption and Economic Growth: A Panel Cointegration Analysis for 16 Asian Countries. International Journal of Environmental Research and Public Health, 14 (11), 1436, 2017.

29. Indicators to measure decoupling of environmental pressure from economic growth. Available online: http:// www.oecd.org/environment/indicators-modellingoutlooks/1933638.pdf (accessed on 5 March 2018)

30. WU Y., ZHU Q., ZHU B. Comparisons of decoupling trends of global economic growth and energy consumption between developed and developing countries. Energy Policy, 116, 30, 2018.

31. NAQVI A., ZWICKL K. Fifty shades of green: Revisiting decoupling by economic sectors and air pollutants. Ecological Economics, 133, 111, 2017.

32. BOQIANG L., LIU K. Using LMDI to Analyze the Decoupling of Carbon Dioxide Emissions from China's Heavy Industry. Sustainability, 9 (7), 1198, 2017.
33. ZHOU X., ZHANG M., ZHOU M., ZHOU M. A comparative study on decoupling relationship and influence factors between China's regional economic development and industrial energy-related carbon emissions. Journal of Cleaner Production, 142, 783, 2017.

34. XU S., ZHANG W., HE Z., HAN H., LONG R., CHEN $H$. Decomposition analysis of the decoupling indicator of carbon emissions due to fossil energy consumption from economic growth in China. Energy Efficiency, 10 (6), $1365,2017$.

35. ZHANG M., BAI C., ZHOU M. Decomposition analysis for assessing the progress in decoupling relationship between coal consumption and economic growth in China. Resources, Conservation and Recycling, 129, 454, 2018.

36. MENG M., FU Y., WANG X. Decoupling, decomposition and forecasting analysis of China's fossil energy consumption from industrial output. Journal of Cleaner Production, 177, 752, 2018.

37. ZHANG M., LIU X., WANG W., ZHOU M. Decomposition analysis of $\mathrm{CO}_{2}$ emissions from electricity generation in China. Energy Policy, 52, 159, 2013.

38. TAPIO P. Towards a theory of decoupling: degrees of decoupling in the EU and the case of road traffic in Finland between 1970 and 2001. Transport Policy, 12 (2), 137, 2005.

39. Guidelines for National Greenhouse Gas Inventories. Available online: www.ipcc-nggip.iges.or.jp/public/2006gl/ vol2.html (accessed on 2 March 2018)

40. DOTSE S., DAGAR L., PETRA M.I., De SILVA L.C. Evaluation of national emissions inventories of anthropogenic air pollutants for Brunei Darussalam. Atmospheric Environment, 133, 81, 2016.

41. ARUNRAT N., WANG C., PUMIJUMNONG N. Reprint of Alternative cropping systems for greenhouse gases mitigation in rice field: a case study in Phichit province of Thailand. Journal of Cleaner Production, 134, 547, 2016.

42. YC X. The struggle for safe nuclear expansion in China. Energy Policy, 73, 21, 2014.

43. MOUSAVI B., LOPEZ N.S.A., BIONA J.B.M., CHIU A.S.F., BLESL M. Driving forces of Iran's CO2 emissions from energy consumption: An LMDI decomposition approach. Applied Energy, 206, 804, 2017.

44. KAHRL F., WILLIAMS J.H., HU J. The political economy of electricity dispatch reform in China. Energy Policy, 53, 361, 2013.

45. SHEN J., LUO C. Overall review of renewable energy subsidy policies in China - Contradictions of intentions and effects. Renewable and Sustainable Energy Reviews, 41, 1478, 2015.

46. SHANG W., PEI G., WALSH C., MENG M., MENG $X$. Have Market-oriented Reforms Decoupled China's $\mathrm{CO}_{2}$ Emissions from Total Electricity Generation? An Empirical Analysis. Sustainability, 8 (5), 468, 2016. 